\title{
Preliminary Design of Kit Kinematics Learning Tools assisted by Phyphox Mobile Apps
}

\author{
${ }^{1}$ Intan Fatmawati, ${ }^{2}$ Dwi Sulisworo \\ 1,2 Magister Pendidikan Fisika, Universitas Ahmad Dahlan, Yogyakarta 55166, Indonesia \\ e-mail: intanfatmawati82@gmail.com; dwi.sulisworo@uad.ac.id;
}

\begin{abstract}
Integration of learning tools with information technology can enrich the learning experience, including in learning physics. This research is the development of kinematics learning tools assisted by Phypox to support the improvement of scientific thinking skills. The scope of kinematics material is horizontal straight motion, vertical straight motion, and circular motion. In this study, the initial design process and design evaluation were carried out. Evaluation of the initial design was carried out by five experts and data were collected using a questionnaire. Data analysis used Content Validity Ratio (CVR) and Content Validity Index (CVI). The analyzed aspects include six indicators, namely: the functional relationship between components, component completeness, work order, practicality, efficiency, and effectiveness. The results of this study indicate that the initial design of the kinematics learning device is in a good category $(C V R=5.60 ; C V I=0.93)$. Thus, this learning tool can be further tested on relevant students. The impact of the use of this tool will not only increase science skills, with certain learning strategies it can also grow the skills of working together and critical thinking.
\end{abstract}

Keywords: Preliminary Design, Physiich Learning, Kinematics, Phyphox

\section{Rancangan Awal Piranti Belajar Kinematika berbantuan Mobile Apps Phyphox}

\begin{abstract}
Abstrak
Integrasi piranti belajar dengan teknologi informasi dapat memperkaya pengalaman belajar termasuk dalam pembelajaran fisika. Penelitian ini merupakan pengembangan piranti belajar kinematika berbantuan Phypox untuk mendukung peningkatan keterambilan berfikir sains. Cakupan materi kinematika adalah gerak lurus horizontal, gerak lurus vertikal, dan gerak melingkar. Dalam penelitian ini dilakukan proses perancangan awal dan evaluasi rancangan. Evaluasi rancangan awal dilakukan oleh lima ahli dan pengumpulan data dikumpulkan dengan angket. Analisis data menggunakan Content Validity Ratio (CVR) dan Content Validity Index $(\mathrm{CVI})$. Aspek yang dianalisis mencakup enam indikator, yaitu: hubungan fungsi antar komponen, kelengkapan komponen, urutan kerja, kepraktisan, efisiensi, dan efektivitas. Hasil penelitian ini menunjukkan bahwa rancangan awal piranti belajar kinematika dalam kategori baik $(C V R=5,60 ; C V I=0,93)$. Dengan demikian, piranti belajar ini dapat diujicobakan selanjutnya pada siswa yang relevan. Dampak penggunaan dari piranti ini selain akan meningkat keterampilan sains, dengan strategi pembelajaran tertentu dapat menumbuhkan pula keterampilan bekerja sama, dan berfikir kritis.
\end{abstract}

Kata Kunci: rancangan awal, pembelajaran fisika, kinematika, Phyphox

How to Cite: Fatmawati, I., Sulisworo, D. (2021). Preliminary Design of Kit Kinematics Learning Tools assisted by Phyphox Mobile Apps. Jurnal Pendidikan Fisika dan Keilmuan (JPFK), 7(1), 13-22. Doi: http://doi.org/10.25273/jpfk.v7i1.9955 


\section{INTRODUCTION}

Learning media is one of the most important tools in the physics learning process (Hochberg, Kuhn, \& Müller, 2018; Mariyo \& Islami, 2019; Widodo \& Islami, 2019). The increasingly massive development of technological developments should be utilized by educators to design effective, innovative, and efficient learning media so that learning objectives can be achieved (Firdaus, Setiawan, \& Hamidah, 2017; Mustafa, Hermandra, \& Zulhafizh, 2019; Yusrizal, Hajar, \& Tanjung, 2019). Of the several technologies that can be utilized in learning, smartphone devices are the most potential to be used in secondary schools (Pierratos \& Polatoglou, 2020).

Utilization of smartphone devices in learning activities is because this device has several excellent features, including being able to detect and generate data from sensors inside the smartphone, easy to use, provides many free applications, and enables a real-time data acquisition system which in its application has proven to be very helpful in the process. physics learning (Nuryantini, Sawitri, \& Nuryadin, 2018; Temiz \& Yavuz, 2015).

In practice, the use of smartphone devices when learning cannot stand alone but requires other supporting devices. One of the supporting applications that are often used and have proven to be reliable is the phyphox app (Staacks, Hütz, Heinke, \& Stampfer, 2018). In addition, another device that needs to be considered is the experimental device, because the data generated by this phyphox app cannot be separated from the real experimental device used.

Several previous research results have also confirmed that the combination between devices greatly determines the quality of the kinematics experimental data obtained (Fayanto, Ishafit, \& Sahlan, 2019; Kittiravechote \& Sujarittham, 2020; Pierratos \& Polatoglou, 2020). However, some of these studies have made experimental tools that are still limited to sub-experiments and have not been integrated into a single kinematics learning tool kit, so that when used in experimental activities in schools they are less efficient. Thus, it is necessary to develop a specially designed kinematics tool integrated with the phyphox app.

\section{RESEARCH METHODS}

This research includes adapted development research (Dieter \& Schmidt, 2009) which aims to produce an initial design of a Phyphox-assisted kinematics learning tool. The stages carried out include 3 phases, namely conceptual design, conceptual prototyping (design embodiment), product prototyping, and design evaluation (design details) as shown in Figure 1.

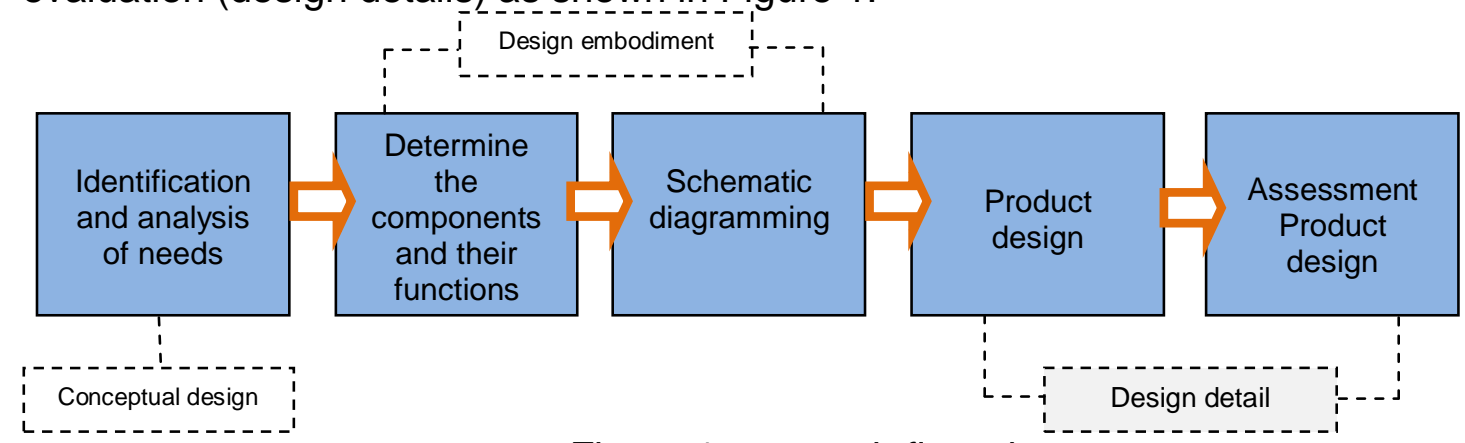

Figure 1. research flow chart

Product design assessment is carried out by adapting testing techniques from (Sugiono, 2019) namely by internal testing by five experts through filling out a questionnaire compiled using six indicators : function relationships between components, component completeness, work order, practicality, efficiency, and effectiveness. The number of questionnaire items is 6 items. The scale used is 0 to 
1. The data analysis technique uses the Content Validity Ratio (CVR) and Content Validity Index (CVI). The results of this calculation become the basis for categorization, where the product is considered feasible if the $\mathrm{CVI}$ is more than 0 (Lawshe, 1975).

\section{RESULTS AND DISCUSSION}

\section{Conceptual design}

The results of the studies that have been carried out show that 21st-century learning requires a digital laboratory to support the physics learning process on kinematics material (Hinnant et al., 2012; Van De Heyde \& Siebrits, 2020). As a solution to these problems, it is necessary to develop the design of kinematics experimental tools for horizontal straight motion, vertical straight motion, and circular motion (kinematics kit). In addition, in designing a kinematics kit, several indicators need to be considered, including simple design, easy to use, thorough, economical, safe to use, good quality, easy maintenance, and integrated with technology.

\section{Design embodiment}

a. Determination of components and their functions

The form of actualization carried out in the manufacture of the kinematics kit which is designed based on the indicators in phase I begins with determining the required components. These components can be seen in Table 2.

Table 2. Kinematics kit components

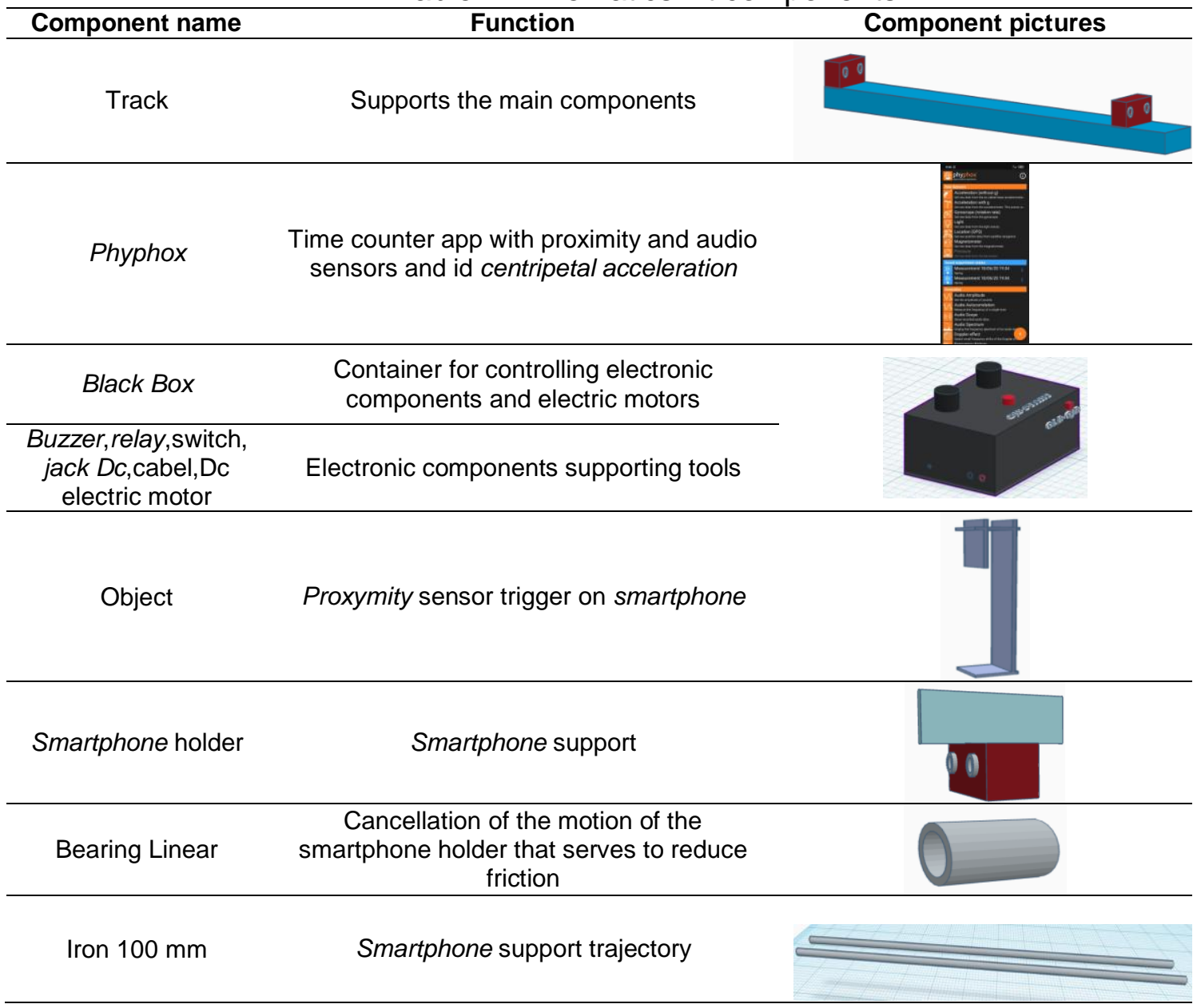




\begin{tabular}{cc}
$\begin{array}{c}\text { Iron stative besi } 5 \\
\mathrm{~mm}\end{array}$ & Magnetic Holding Support \\
Stand Statif & Stative Support and Spherical Disc \\
Holding Magnet & Drag and drop objects \\
Circle plate & Circular path of object (smartphone) \\
\hline
\end{tabular}

b. Skematic diagramming

1) Horizontal straight motion schematic diagram

Table 3. Schematic diagram of horizontal straight motion

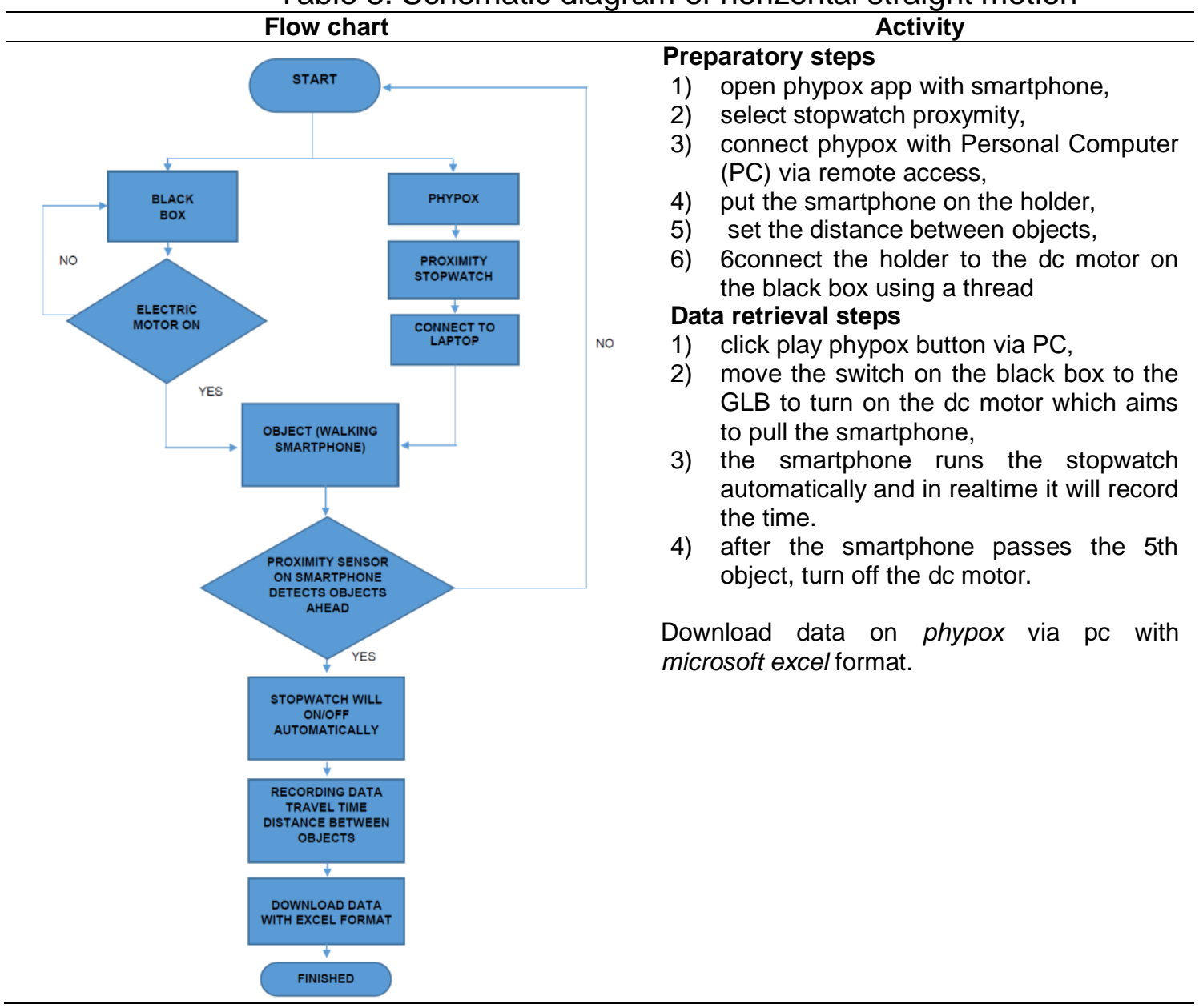


2) Vertical straight motion schematic diagram

Table 4. Schematic diagram of vertical straight motion

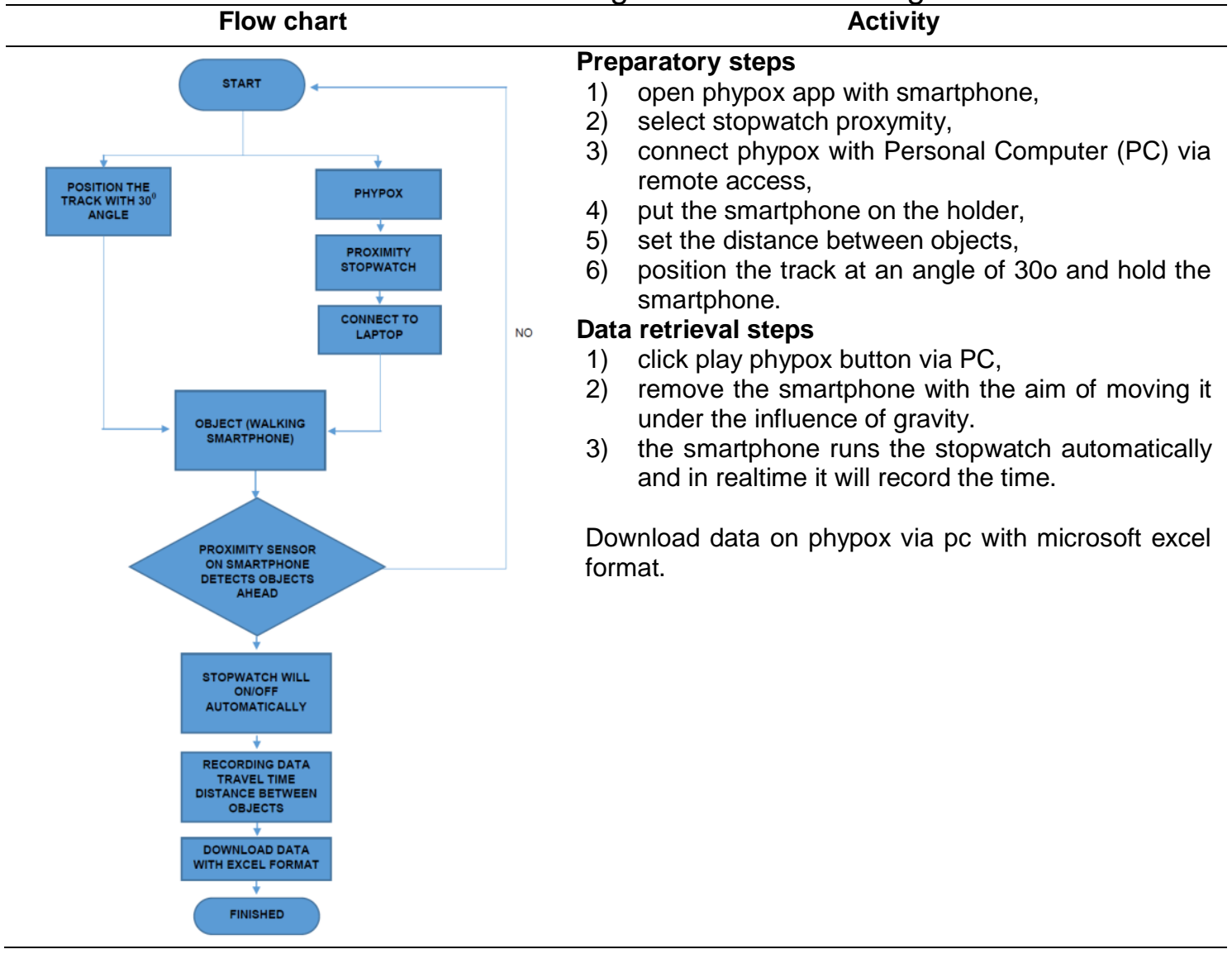

3) Free fall motion schematic diagram

Table 5. Free fall motion schematic diagram

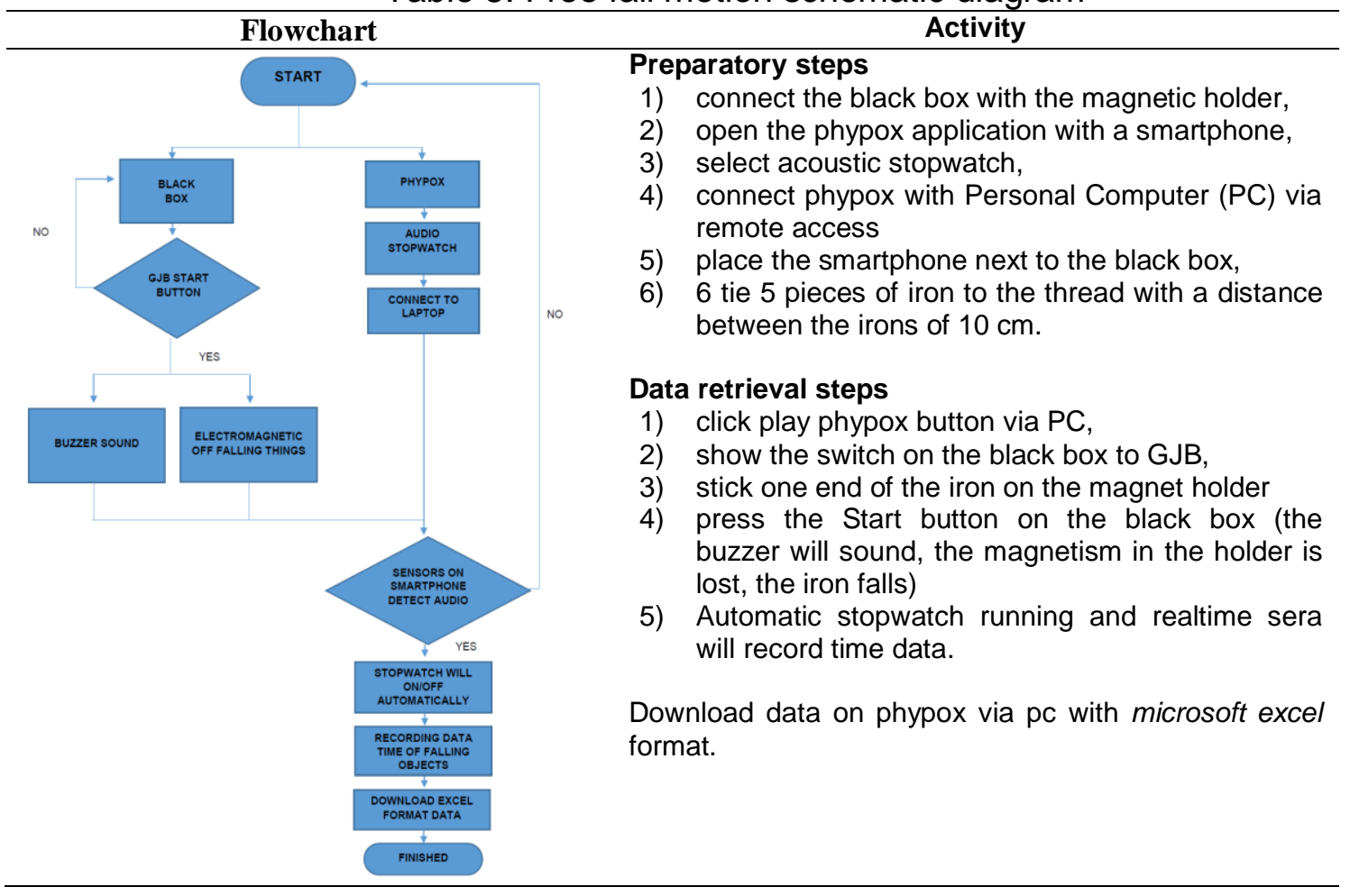


4) Schematic diagram of uniform circular motion

Table 6. Schematic diagram of uniform circular motion Flowchart Activity

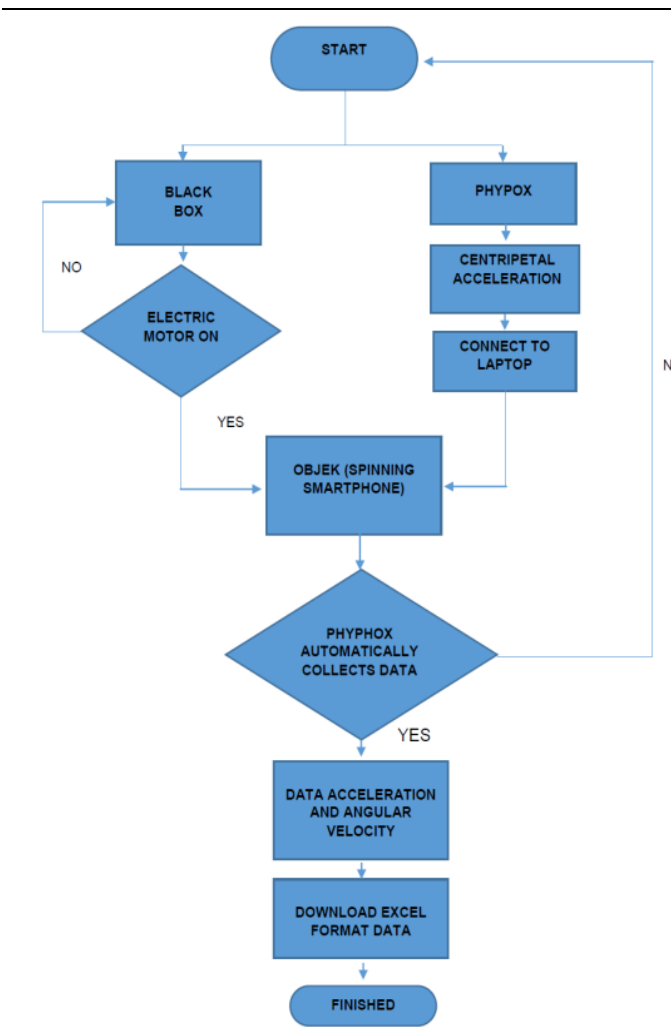

Preparation steps

1) open phyphox app with smartphone,

2) select Centripetal acceleration,

3) connect phypox with Personal Computer $(\mathrm{PC})$ via remote access,

4) Place the smartphone on a round disc.

Data retrieval steps

1) open the phyphox application with a smartphone,

2) select centripetal acceleration,

3) connect phypox with a personal computer $(\mathrm{PC})$ via remote access,

4) place the smartphone on a round disc.

Download data on phyphox via pc with microsoft excel format.

\section{Phase III Design Details}

\section{a. Kinematics kit design creation}

In this phase, the activity carried out is making a kinematics kit design, the main activity is divided into 2 , namely making a black box scheme design using the Proteus application and designing a detailed 3D kinematics kit display using Tinkercad. The results of the black box scheme design are shown in Figure 6.7 and the kinematics kit of horizontal straight motion, vertical straight motion, and circular motion can be seen in Table 7 as follows:

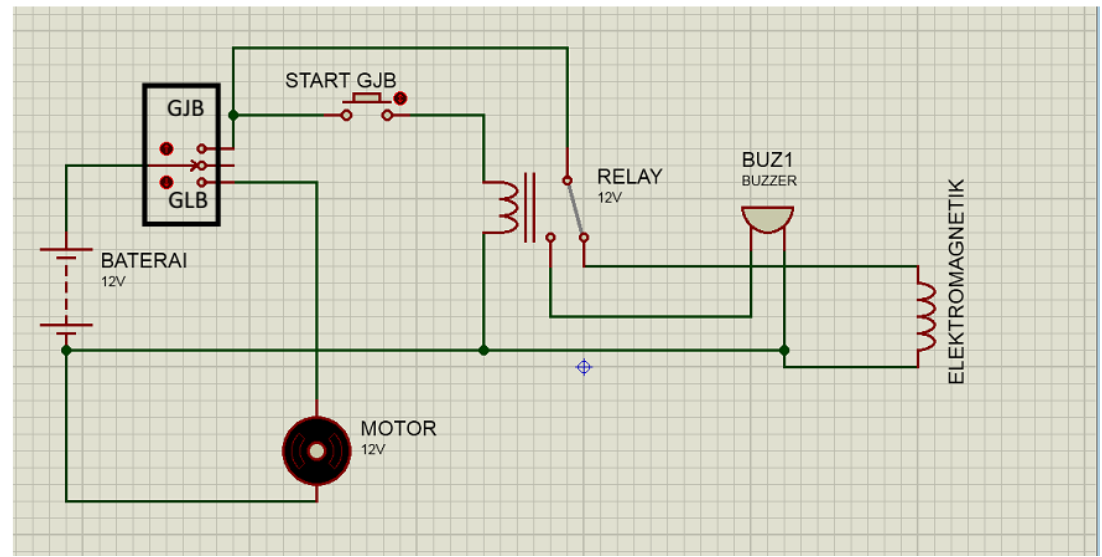

Figure 6. black box scheme 


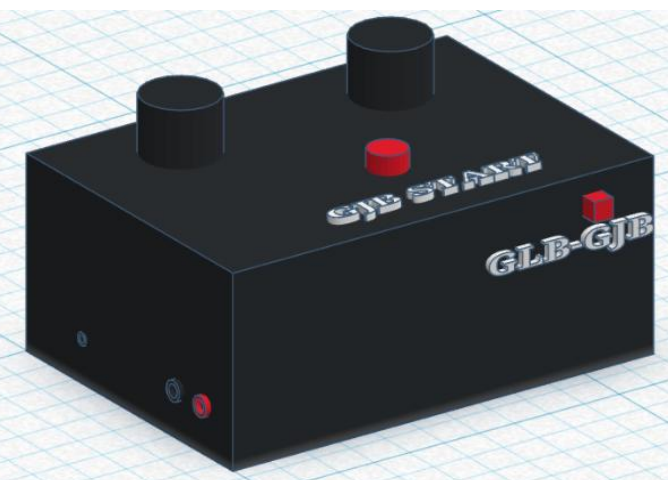

Figure 7. black box display design

Table 7. Conceptual drawings and finished products

\section{Conceptual image Finished product}
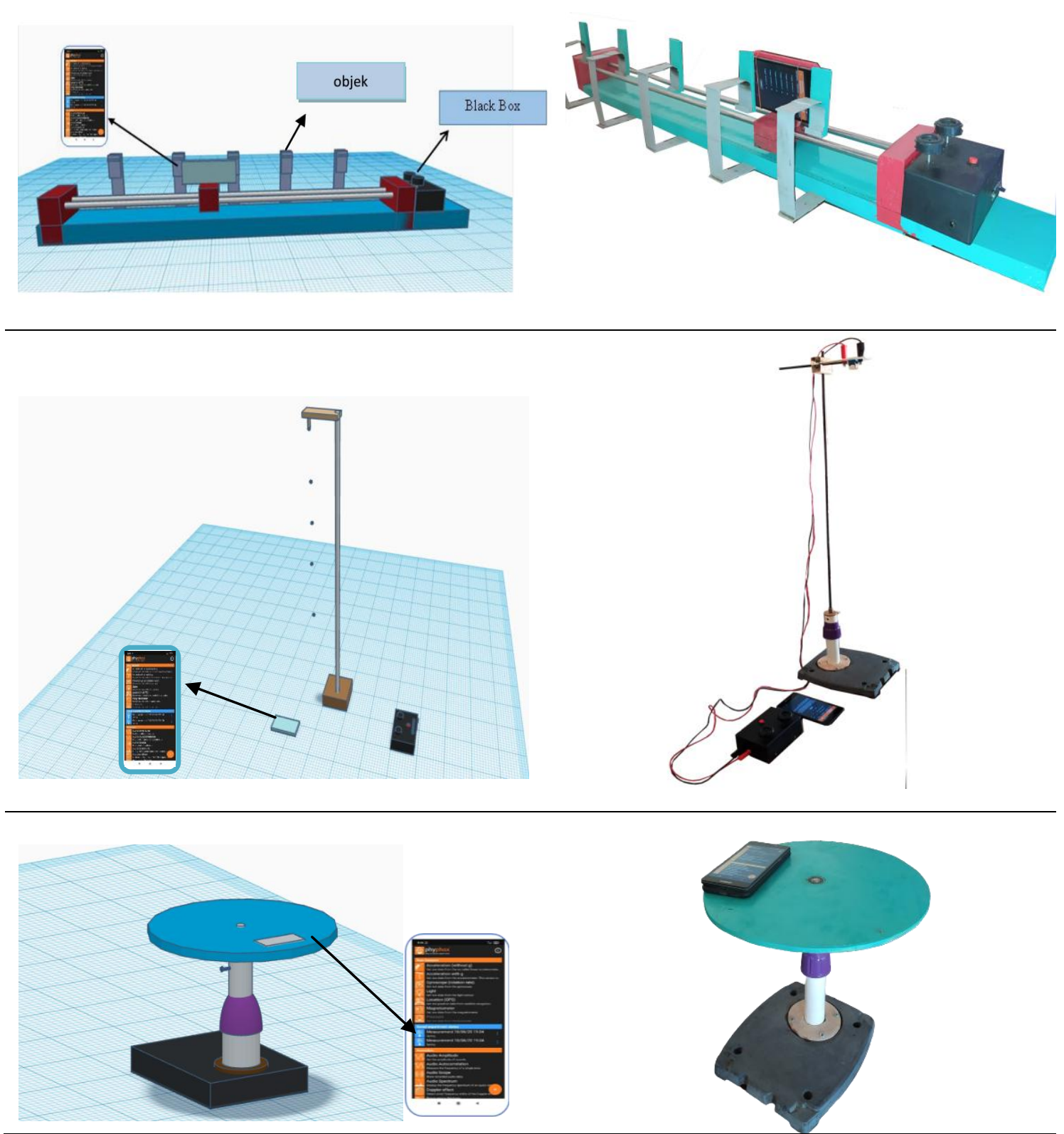
b. Product design assessment

The last stage of the development of the kinematics kit design is an evaluation of the assessment by 5 experts which aims to determine the quality of the design that has been made. At this stage, the evaluation of media design is carried out using a questionnaire instrument with 6 indicators adapted from (Sugiono, 2019). The data obtained were then analyzed quantitatively using CVR and CVI. The results of the CVR and CVI analysis shown in table 8 obtained a $C V I$ score of 0.93 meaning that the media design developed was valid and had good quality.

Table 8. Analysis of CVR and CVI

\begin{tabular}{|c|c|c|c|c|c|c|c|}
\hline \multirow{2}{*}{ Indicator } & \multicolumn{5}{|c|}{ Validator } & \multirow{2}{*}{$C V R$} & \multirow{2}{*}{ Description } \\
\hline & 1 & 2 & 3 & 4 & 5 & & \\
\hline $\begin{array}{l}\text { Functional relationship between } \\
\text { components }\end{array}$ & 1 & 1 & 1 & 1 & 1 & 1,00 & Valid \\
\hline Completeness of components & 1 & 1 & 1 & 1 & 1 & 1,00 & Valid \\
\hline Order of work & 1 & 1 & 1 & 0 & 1 & 0,60 & Valid \\
\hline Practicality & 1 & 1 & 1 & 1 & 1 & 1,00 & Valid \\
\hline Efficiency & 1 & 1 & 1 & 1 & 1 & 1,00 & Valid \\
\hline Effectiveness & 1 & 1 & 1 & 1 & 1 & 1,00 & Valid \\
\hline \multicolumn{6}{|c|}{$\begin{array}{l}\text { TOTAL CVR } \\
\end{array}$} & 5,60 & Valid \\
\hline CVI & & & & & & 0,93 & Valid \\
\hline
\end{tabular}

The assessment results obtained indicate that the developed media has an attractive appearance, is simple, easy to use, and is time-efficient, so the media deserves a good assessment (Istiantara et al., 2019; Karo-Karo \& Rohani, 2018; Pierratos \& Polatoglou, 2020; Widiantama \& Pramono, 2019). This media is also used in collaboration with the phyphox apps which have been proven reliable and have data accuracy, and can be presented in realtime (Ishafit \& Wahyuni, 2019; Pierratos \& Polatoglou, 2020; Pusch, Ubben, Laumann, Heinicke, \& Heusler, 2021; Suyanto \& Herlina, 2020). The voltage source used in this medium is a DC $5 \mathrm{v}$ current that can be recharged, so it is environmentally friendly and will increase the safety factor when used.

Other results obtained from the evaluation stage are several suggestions were given by experts, including 1) Installation of the buzzer should be placed on the black box, 2) the voltage component of the voltage is lowered to 5 volts so that it can work with a battery voltage source, 3) installation of a length measuring instrument on the mainframe.

\section{CONCLUSION}

This research resulted in the initial design of the kinematics kit and its working system. The evaluation results from the kinematics kit design expert are of very good quality. Based on these results, the design of the kinematics kit can be continued to the next stage, namely the trial process in schools.

\section{REFERENCE}

Dieter, G. E., \& Schmidt, L. C. (2009). Engineering design: McGraw-Hill Higher Education Boston.

Fayanto, S., Ishafit, \& Sahlan. (2019). Theoretical and experimental studies on centripetal acceleration using the Phyphox application. International Journal of Scientific and Research Publications (IJSRP), 9(9), p9322. doi: 10.29322/IJSRP.9.09.2019.p9322 
Firdaus, T., Setiawan, W., \& Hamidah, I. (2017). The kinematic learning model using video and interfaces analysis. Paper presented at the Journal of Physics: Conference Series.

Hinnant, C. C., Stvilia, B., Wu, S., Worrall, A., Burnett, G., Burnett, K., . . Marty, P. F. (2012). Author-team diversity and the impact of scientific publications: Evidence from physics research at a national science lab. Library \& Information Science Research, 34(4), 249-257.

Hochberg, K., Kuhn, J., \& Müller, A. (2018). Using smartphones as experimental tools-effects on interest, curiosity, and learning in physics education. Journal of Science Education and Technology, 27(5), 385-403.

Ishafit, I., \& Wahyuni, M. E. (2019). Determination the coefficient of restitution in object as temperature function in partially elastic collision using phyphox application on smartphone. Science and Technology Indonesia, 4(4), 88-93.

Istiantara, D., Mafudi, I., Handhika, J., Huriawati, F., Astutik, S., \& Rachman, N. (2019). Implementing microcontroller-based straight motion practicum media for improving scientific processing skills. Paper presented at the Journal of Physics: Conference Series.

Karo-Karo, I. R., \& Rohani, R. (2018). Manfaat media dalam pembelajaran. AXIOM: Jurnal Pendidikan Dan Matematika, 7(1).

Kittiravechote, A., \& Sujarittham, T. (2020). Measuring the Acceleration of Gravity Using a Smartphone, A4-Papers, and a Pencil.

Lawshe, C. H. (1975). A quantitative approach to content validity. Personnel psychology, 28(4), 563-575.

Mariyo, H., \& Islami, N. (2019). Development of Sound Wave Experimentation Tools Which Influenced by Relative Humidity Using Audacity. Paper presented at the Journal of Physics: Conference Series.

Mustafa, M. N., Hermandra, H., \& Zulhafizh, Z. (2019). Teachers' Strategies to Design Media to Implement Communicative Leaning in Public Schools. Journal of Educational Sciences, 3(1), 13-24.

Nuryantini, A. Y., Sawitri, A., \& Nuryadin, B. W. (2018). Constant speed motion analysis using a smartphone magnetometer. Physics Education, 53(6), 065021.

Pierratos, T., \& Polatoglou, H. M. (2020). Utilizing the phyphox app for measuring kinematics variables with a smartphone. Physics Education, 55(2), 025019.

Pusch, A., Ubben, M. S., Laumann, D., Heinicke, S., \& Heusler, S. (2021). Real-time data acquisition using Arduino and phyphox: measuring the electrical power of solar panels in contexts of exposure to light in physics classroom. Physics Education, 56(4), 045001.

Staacks, S., Hütz, S., Heinke, H., \& Stampfer, C. (2018). Advanced tools for smartphone-based experiments: phyphox. Physics education, 53(4), 045009.

Sugiono. (2019). Metode Penelitian dan Pengembangan (Research and Development/R\&D) (Sofia Yustiyani Suryandar ed.). Yogyakarta: Alfabeta.

Suyanto, E., \& Herlina, K. (2020). The Effect of GIL Assisted Phyphox in Physics Learning towards Creative Thinking. Jurnal Pembelajaran Fisika, 8(2), 141-150.

Temiz, B. K., \& Yavuz, A. (2015). Magnetogate: using an iPhone magnetometer for measuring kinematic variables. Physics Education, 51(1), 015004.

Van De Heyde, V., \& Siebrits, A. (2020). Digital laboratory report writing, assessment and feedback in the 21st century for an extended curriculum programme for physics. Research in Science \& Technological Education, 1-32.

Widiantama, O., \& Pramono, H. (2019). Development of Practicum Tools DC Motor Speed Control System as a Learning Media of Robotics Learning Practice. Paper presented at the Journal of Physics: Conference Series. 
Widodo, A., \& Islami, N. (2019). Development of Physics Learning Media on Rotational Materials Based on Interactive Multimedia. Paper presented at the Journal of Physics: Conference Series.

Yusrizal, Y., Hajar, I., \& Tanjung, S. (2019). Analysis of Elementary School Teachers' Ability in Using ICT Media and Its Impact on the Interest to Learn of Students in Banda Aceh. Budapest International Research and Critics in Linguistics and Education (BirLE) Journal, 2(3), 45-57. 